\title{
REPRESENTASI PEREMPUAN DALAM KOLOM HUMOR SI PALUI DI BANJARMASIN POST
}

\author{
Irene Santika Vidiadari \\ Program Studi Ilmu Komunikasi \\ Fakultas Ilmu Sosial dan Ilmu Politik \\ Universitas Atma Jaya Yogyakarta \\ E-mai: irene_santika@staff.uajy.ac.id
}

\begin{abstract}
The focus of this paper is the representation of women on Banjarmasin Post's humour column, "Si Palui," whose stories are either about daily lives or domestic issues. On the latter topic, the theme which regularly appears is marital problems such as poligamy, divorce, and sexuality. On this column, women characters are merely supporting casts and, hence, are subordinated. This research applies the critical language element of the micro level of Norman Fairclough's Critical Discourse Analysis in order to understand the representation issues through language: semantics, syntax, and lexycon. Th result shows that the representation of women on Si Palui is categorized into three: as widows, wives, and other kinds of women. The widows are illustrated as having plumpy body and always expecting to get married, though the representation emphasizes on the kind of flirtious widows adored by men. The wives are represented as the sexual objects of their husband. Meanwhile other kinds of women, such as mother-in-laws, are fussy, and single women are agressive.
\end{abstract}

\begin{abstract}
Abstrak
Tulisan ini berfokus untuk melihat representasi perempuan dalam kolom humor berbahasa Banjar, Si Palui di Banjarmasin Post. Humor Si Palui menceritakan kejadian sehari-hari dan membahas persoalan rumah tangga. Pada cerita Palui yang bertema rumah tangga, beberapa tema yang sering hadir adalah poligami, perceraian, dan seksualitas suami istri. Pada kolom Si Palui, tokoh perempuan hadir sebagai figuran dan subordinat. Penelitian ini menggunakan elemen critical language dari level mikro pada analisis wacana Fariclough untuk membedah persoalan representasi melalui aspek bahasa: semantik, sintaksis dan leksikon. Hasil penelitian ini menunjukkan bahwa representasi perempuan dalam teks Si Palui terbagi menjadi tiga: sebagai janda, istri, dan status perempuan lain digambarkan berbeda-beda. Tokoh janda digambarkan sebagai tokoh yang berbadan montok, manja, dan ingin segera menikah. Tokoh janda yang mendapat penegasan dalam kolom Palui adalah janda kembang yang menjadi idola laki-laki. Tokoh istri digambarkan sebagai objek seksual suaminya. Perempuan lain, seperti mertua, digambarkan cerewet, dan perempuan lajang diceritakan agresif.
\end{abstract}

Keywords: Representation, Subordinate, Critical Language 


\section{PENDAHULUAN}

Teks, dalam pengertian yang luas merupakan produk dari sebuah diskursus, yaitu tindak penggunaan dan pertukaran tanda dan bahasa dalam bentuk verbal maupun visual (Piliang, 2004: 190). Teks yang berbentuk verbal kemudian dibagi lagi menjadi teks oral dan teks tertulis. Beberapa bentuk teks tertulis antara lain buku, novel, artikel surat kabar, cerita humor, dan lainnya.

Memahami teks bukanlah sebatas memahami maksud dalam teks tersebut, namun secara lebih menyeluruh harus melihat pula tekstur dari teks tersebut, bentuk, danorganisasiyang melatarbelakangi kemunculannya. Teks merupakan sebuah proses sosial yang secara simultan muncul dalam sebuah masyarakat. Oleh karena itu, teks menjadi sebuah gambaran dari pola pikir dan representasi dari sebuah masyarakat.

Kolom cerita humor merupakan salah satu bentuk teks yang dapat dikaji untuk melihat representasi masyarakat produsen humor sendiri. Kemunculan kolom humor juga seringkali berawal dari budaya lisan masyarakat. Sehingga teks humor kemudian dituliskan dan disebarkan melalui medium tertentu. Kolom humor Si Palui adalah salah satu bentuk teks yang berangkat dari tradisi lisan yang kemudian dituliskan dan disebarkan melalui surat kabar Banjarmasin Post.

Wijana (1995) menjelaskan bahwa humor tidak saja bermanfaat sebagai wahana hiburan, tetapi berguna pula sebagai sarana pendidikan dan kritik sosial bagi semesta ketimpangan yang akan, sedang, atau telah terjadi di tengah masyarakat penciptanya. Di sisi lain, teks-sebagai sesuatu yang tidak pernah lepas dari konteks sosialjuga dipahami sebagai sesuatu yang selalu membawa nilai dan ideologi.

Pada proses pemanfaatan humor, bahasa menjadisaranayangpaling tepat,yang dipakai dalam mengemukakan humor tersebut. Bahasa merupakan alat komunikasi sosial yang merupakan hasil budaya masyarakat sehingga identitas bahasa sebagai humor hanya dapat dimaknai sepenuhnya oleh masyarakat itu sendiri (Rizkie, 2013: 1).

Humor, pada dasarnya adalah hasil dari sebuah persepesi budaya-baik individu maupun kelompok. Humor amat bergantung pada konsep budaya yang dimiliki bersama, sehingga amat sulit memahami sebuah humor tanpa adanya kesamaan latar belakang, konsep budaya dan konteksnya (Pormes, 2015: 2).

Yuniawan (2005: 289-291) mengemukakan bahwa dari aspek kebahasaan dalam humor, kehadiran tokoh perempuan sering dijadikan objek dari humor tersebut. Secara khusus, perempuan menjadi objek pada humor yang berasosiasi dengan pornografi. Pada persoalan pornografi, humor ditujukan untuk menyinggung hal-hal yang bersifat erotis dan menimbulkan hasrat seksual. Pada humor-humor yang memiliki asosiasi dengan pornografi, perempuan hadir sebagai pihak yang menjadi objek, yang ditunjukkan dari pemilihan kata dan penggunaan majas.

Kolom humor Si Palui di Banjarmasin Post merupakan teks berbahasa Banjar yang menceritakan seorang laki-laki bernama Si Palui sebagai tokoh utama. Selain Palui, tokohyang sering hadir dalam kolom tersebut adalah Garbus, dan Tulamak. Ciri khas dari kolom ini adalah, Palui selalu saja menjadi tokoh yang menang telak dalam setiap obrolan. Hadir sejak tahun 1971, Si Palui sebagai salah satu kolom di Banjarmasin Post telah menjadi ciri khas dari surat kabar ini dan terus dipertahankan eksistensinya hingga sekarang.

Cerita Si Palui tidak serta merta dibuat untuk Banjarmasin Post. Cerita ini telah mengalami perjalanan panjang sebagai cerita dalam budaya lisan orang Banjar yang kemudian diangkat sebagai salah satu kolom hiburan di Banjarmasin Post. Di surat kabar Banjarmasin Post, Si Palui adalah cerita yang sifatnya lepas dan tidak bersambung antaredisi. Cerita ini dipertahankan karena Palui telah sejak awal dinobatkan sebagai maskot surat kabar ini. Tema-tema yang diangkat dalam kolom ini adalah seputar kehidupan sehari-hari, seperti Palui yang berganti-ganti pekerjaan, Palui yang sedang 
menjaga anaknya, hingga cerita-cerita yang berhubungan dengan masalah rumah tangga.

Pada beberapa edisi, Palui diceritakan melakukan poligami, menggoda perempuan lain, diam-diam menikah siri, maupun halhal lain yang tidak jauh dari persoalan rumah tangga. Tokoh-tokoh yang hadir dalam kolom Si Palui tidak hanya Palui dan kedua temannya-Garbus dan Tulamak. Tidak jarang muncul tokoh-tokoh perempuan seperti istri Palui, penjaga warung kopi, janda di kampungnya, atau tokoh perempuan lain. Saat membicarakan tentang perempuanatau pada saat perempuan hadir sebagai lawan bicara si Palui-topik pembicaraan tidak jauh-jauh dari urusan rumah tangga, termasuk di dalamnya perihal poligami, perceraian, atau sekadar urusan memiliki anak. Palui memiliki karakteristik suka menggoda perempuan, di samping karakter utamanya sebagai orang yang selalu menang dalam berbagai adu argumen dengan lawan bicaranya.

Berperan sebagai tokoh utama, si Palui selalu menjadi pusat perhatian dalam setiap ceritadi kolomini. Ia tidakpernah kalah dalam berbagai perbincangan dengan orang-orang di sekitarnya, termasuk dengan perempuan. Pada teks-teks Si Palui, perempuan hadir sebagai figuran, bahan pembicaraan, dan objek dari lelucon yang dilontarkan oleh si Palui dan teman-temannya. Tidak ada perempuan yang hadir sebagai tandingan dari tokoh si Palui dalam adu argumen atau melempar lelucon. Terkadang perempuan hadir sebagai bahan cerita di antara si Palui dan teman-temannya, meskipun tanpa kehadiran perempuan yang menjadi bahan pembicaraan.

Ketidakhadiran perempuan yang ikut mengambil porsi lebih banyak dalam cerita atau digambarkan memiliki posisi lebih penting daripada sekadar sebagai objek lelucon dalam kolom Si Palui menghadirkan permasalahan tersendiri, terutama mengenai relasi antara perempuan dan laki-laki dalam kolom cerita. Dominasi cerita oleh laki-laki dan tidak berimbangnya penggambaran perempuan menghadirkan stereotip dan misrepresentasi tentang perempuan dalam kolom Si Palui. Kehadiran perempuan dalam kolom Palui selalu saja menjadi objek dari humor, baik mereka yang digoda secara "langsung" oleh Palui dan teman-temannya maupun yang tidak hadir dan hanya menjadi bahan perbincangan. Pada cerita-cerita dalam kolom ini terjadi ketimpangan, di mana penokohan utama adalah laki-laki dan Palui sendiri tidak memiliki tokoh tandingan perempuan sebagai lawan bicaranya.

Tulisan ini berfokus pada representasi perempuan dalam kolom Si Palui di Banjarmasin Post. Stuart Hall (1997: 17) mengemukakan bahwa representasi merupakan produksi makna dari satu konsep tertentu di dalam pikiran kita melalui bahasa. Representasi menjembatani konsep dan bahasa yang memungkinkan seseorang membedakan antara sesuatu yang nyata dan fiksi. Pada penjelasannya tentang representasi, Stuart Hall (1997) mengemukakansebuahsirkuitbudaya, bahwa representasi sangat bergantung pada faktorfaktor budaya seperti: regulasi, identitas, produksi, konsumsi, dan distribusi. Produksi gambaran yang terjadi secara terus menerus inilah yang kemudian tertanam dan secara otomatis membawa pemaknaan tertentu di dalam diri seseorang ketika pancaindranya menangkap satu stimulus yang dapat dimaknai lalu muncullah representasi.

Proses pemaknaan akan sesuatu tidak pernah lepas dari faktor sosial dan budaya di sekitarnya. Representasi berangkat dari pemaknaan akan bahasa yang dipakai oleh masyarakat yang berbagi makna. Lebih dalam lagi, pemaknaan berdasar dari tataran ideologis seseorang. Bahasa merupakan media yang secara spesifik membuat individu sadar akan sesuatu, dan dari situlah makna diproduksi dan dipertukarkan. Makna hanya bisa dibagi dengan akses bahasa yang dipahami secara bersama. Oleh sebab itu bahasa adalah hal utama yang terkait dengan pemaknaan dan budaya. Bahasa dipahami pula sebagai kata kunci dari nilai budaya dan makna.

Representasi, sebagai bagian dari praktik diskursus, tidak pernah lepas 
dari efek struktural yang menyertainya. Oleh karena itulah Fairclough (1989: 74) mengemukakan pembagian sistematis yang kemudian menghasilkan sebuah relasi sosial. Pembagian ini melihat bagaimana (1) subjek yang memiliki efek untuk mencirikan sebuah identitas sosial, (2) relasi antarsubjek yang merepresentasikan relasi sosial, dan (3) konten yang merepresentasikan sebuah pengetahuan. Pembagian sistematis di atas kemudian dapat menjadi acuan bagaimana relasi dan identitas yang hadir melalui representasi di dalam teks media.

Representasi ini hadir baik dengan menggunakan gambar maupun bahasa dan narasi untuk mendeskripsikan sesuatu. Terkait dengan penjabaran Fairclough di atas, antara representasi, relasi dan identitas memiliki keterkaitanyang sangaterat. Ketiganya menjadi bagian dalam teks yang mengkonstruksikan makna atas segala sesuatu.

Fenomena kultural tentang gender melihat bahwa perempuan hidup dalam eksistensi sosial yang terkungkung dan terkekang oleh budaya patriarki (Anwar, 2009: 51). Pada fenomena ini hadir sebuah kondisi di mana perempuan hidup dalam dualitas kultural: sebagai anggota kultur umum laki-laki dan dalam kultur perempuan yang spesifik. Dualitas kultural yang menyelimuti kehidupan perempuan tersebut yang kemudian menimbulkan konflik subjek-objek, yang dalam kebudayaannya didominasi oleh laki-laki, sementara perempuan dianggap sebagai jenis kelamin kedua (liyan) dalam sistem kebudayaan patriarki. Penempatan subjek-objek ini tidak juga lepas dari bagaimana perempuan direpresentasikan di media.

Ketika perempuan direpresentasikan di media, identitas perempuan banyak diatur oleh hal-hal yang berada di luar dirinya. Menurut Thornham (2010: 174) mengemukakan bahwa perempuan kerap kali menjadibendayangdipertukarkan, dibentuk, dan dikonsumsi oleh laki-laki dan budaya patriarki yang berlaki. Hal ini yang membuat perempuan kehilangan kuasa, termasuk kuasa untuk menentukan identitasnya. Penghilangan kuasa atas identitas ini yang menyebabkan perempuan berada pada posisi objek. Relasi antara perempuan sebagai objek dan laki-laki sebagai subjek mengukuhkan keliyanan perempuan dalam berbagai bentuk teks, termasuk teks media.

Penelitian mengenai representasi perempuan di media massa banyak dilakukan oleh tokoh-tokoh feminis. Laura Mulvey (1975) adalah salah satunya. Pada penelitiannya mengenai representasi perempuan dalam film (Mulvey, dalam Storey 2015: 110) yang mengemukakan bahwa posisi perempuan dalam suatu media ditampilkan sebagai objek erotis (erotic object) dalam dua level. Pertama, sebagai objek erotis dalam narasi media, yakni bahwa karakter perempuan dalam media ditransformasikan sebagai objek hasrat dari tokoh laki-laki. Kedua, perempuan menjadi objek erotis dari penonton itu sendiri. Citra perempuan dalam media tidak pernah lepas dari sudut pandang laki-laki sebagai penonton.

Kenikmatan menonton ini yang menyebabkan perempuan berada pada posisi pasif (sebagai yang ditonton) dan laki-laki berada pada posisi aktif (pihak yang menonton). Sebagai penonton yang aktif, sudut pandang laki-laki dan fantasinya dipakai untuk memproyeksikan perempuan sedemikian rupa pada figur-figur perempuan di media yang telah diatur sehingga kehadiran perempuan dalam representasi media memiliki posisi bukan sebagai subjek yang memiliki kekuasaan atas dirinya melainkan sebagai objek dengan sudut pandang bagaimana laki-laki ingin melihat perempuan menurut citranya (Mulvey, dalam Storey 2015: 111).

Humor sebagai salah satu bentuk hiburan juga memiliki fungsi sebagai kritik sosial atas berbagai kondisi sosial yang terjadi. Hal ini yang kemudian melahirkan humor dalam berbagai tema besar seperti humor politik, humor sosial, humor seksual, humor agama, dan sebagainya yang hadir dalam bentuk tulisan seperti cerita humor, kartun, dan komik. Pada bentuk humor lisan, dalam budaya beberapa daerah di Indonesia terdapat humor yang disampaikan melalui pertunjukan ludruk dan ketoprak. 
Pada teks-teks humor, humor dapat ditelaah melalui teori linguistik: semantik, dan pragmatik humor (Soedjatmiko, 1992 dalam Maryam, 2014: 17). Sisi semantik humor memanfaatkan keambiguan dengan mempertentangkan dua makna atas satu kata yang sama. Kelucuan muncul ketika makna yang diambil ternyata salah. Semantik humor memanfaatkan keambiguan pada tataran kata, kalimat serta wacana. Pada level humor yang lebih panjang seperti humor kolom dan sastra, kelucuan tercapai karena adanya penyimpangan terhadap maksimmaksim tuturan, keyakinan konvensional, dan pengetahuan yang melatarbelakangi pengalaman humoris penikmat humor tersebut.

\section{METODE}

Penelitian ini merupakan penelitian kualitiatif dengan menggunakan sumber data teks dari kolom Si Palui. Analisis data dilakukan dengan melihat unsurunsur linguistik yang diadopsi dari analisis level mikro pada analisis wacana Norman Fairclough (1995). Fairclough (1995: 98) mengemukakan bahwa teks dianalisis dengan critical linguistic atau membedah teks melalui elemen-elemen linguistik. Pada penelitian ini, elemen linguistik yang dipakai adalah elemen semantik, sintaksis, dan leksikon. Melalui ketiga elemen tersebut dapat dilihat representasi yang muncul di dalam teks.

Teks Si Palui yang dipilih merupakan teks yang menampilkan cerita tentang tokoh perempuan. Pada tulisan ini, telah dipilih lima tulisan:

\begin{tabular}{ll}
\hline \multicolumn{1}{c}{ Tanggal Terbit } & \multicolumn{1}{c}{ Judul } \\
\hline 19 Januari 2016 & $\begin{array}{l}\text { Janda Kambang } \\
\text { (Janda Kembang) }\end{array}$ \\
\hline 26 Januari 2016 & $\begin{array}{l}\text { Mancariakan Abahnya } \\
\text { (Mencari Ayahnya) }\end{array}$ \\
\hline 2 Maret 2016 & $\begin{array}{l}\text { Baubah Banar } \\
\text { (Sangat Berubah) }\end{array}$ \\
\hline 17 Maret 2016 & $\begin{array}{l}\text { Cagar Batiga } \\
\text { (Akan Bertiga) }\end{array}$ \\
\hline 23 Maret 2016 & $\begin{array}{l}\text { Cangkir Baciri } \\
\text { (Cangkir Berciri) }\end{array}$ \\
\hline
\end{tabular}

\section{HASIL DAN PEMBAHASAN}

\section{Kolom Humor Si Palui}

Palui merupakan salah satu nama tokoh yang sering dijadikan ceritadalam masyarakat Banjar. Nama Palui bukan berarti tanpa makna. Palui berasal dari kata mamalui, sebuah kebiasaan bercanda pada masyarakat Banjar. Vidiadari (2013: 77) mengemukakan bahwa kekhasan dari mamalui atau disingkat dengan malui ini adalah bentuk humornya yang menukik, menyindir dengan terangterangan, tepat sasaran, dan menjadi gong dari humor itu. Orang yang jago malui ini kemudian dikenal sebagai Palui.

Jauh sebelumSi Palui hadirsebagai kolom cerita humor di surat kabar Banjarmasin Post, tokoh Palui hadir sebagai tokoh fiktif yang berkembang dalam cerita-cerita rakyat di Banjar Kuala, yakni daerah Banjarmasin dan Marabahan. Jika menengok pada budaya daerah lain, Palui dapat disejajarkan dengan Kabayan dari daerah Sunda. Karakter Palui bermacam-macam tergantung penuturnya. Kadang digambarkan sebagai tokoh yang bijaksana, terkadang polos dan ceroboh, tapi tetap saja lucu. Di daerah Kalimantan Selatan yang lain seperti Martapura, tokoh yang sering dijadikan bahan cerita adalah tokoh si Anang, sedangkan daerah Hulu Sungai seperti Amuntai, Barabai, dan Kandangan, tokoh yang sering diceritakan adalah tokoh si Utuh.

Kehadiran Palui bermula dari tradisi lisan orang Banjar, sehingga cerita Palui bermuatan nasihat dan pesan moral tertentu. Tak jarang cerita Si Palui dituturkan pada pertunjukkan madihin, yaitu pertunjukkan tradisional Banjar yang menghadirkan satu atau dua orang yang saling berbalas pantun atau menuturkan cerita dengan iringan tarbang (dalam dialek Banjar, atau terbang, adalah alat musik yang mirip rebana dengan diameter yang lebih besar dan dipakai dalam kesenian madihin). Pertunjukkan madihin ini sering dilakukan pada acara-acara besar seperti pada saat pernikahan, peringatan keagamaan seperti Maulid Nabi Muhammad SAW, atau perayaan besar lainnya. 
Pada tahun 1971, Si Palui diangkat menjadi salah satu rubrik di Banjarmasin Post dengan judul "Kisah Bahasa Banjar" yang diletakkan pada halaman terakhir surat kabar tersebut. Seiring berjalannya waktu, kolom ini dipindah ke halaman pertama Banjarmasin Post.

Penulis pertama kolom Si Palui di Banjarmasin Post adalah Yustan Aziddin, salah seorang pendiri Banjarmasin Post. Tujuan kehadiran kolom ini tidak sekadar untuk mengisi kekosongan kolom di surat kabar Banjarmasin Post tetapi juga untuk mengangkat budaya lokal Banjar. Yustan Aziddin sebagai tokoh yang mencetuskan ide untuk menghadirkan kolom dengan muatan budaya lokal sejak awal menetapkan konsep Palui sebagai kolom yang "bebas" artinya tidak bergantung pada berita utama di hari itu. "Kebebasan" kolom Si Palui ini berangkat dari tujuan semula bahwa kolom ini merupakan cerita bahasa banjar yang membahas persoalan sehari-hari di masyarakat Banjar (berdasarkan hasil wawancara dengan redaksi Banjarmasin Post, 22 Juni 2016).

Tema-tema yang dipilih untuk cerita Si Palui tidak pernah jauh dari kehidupan bermasyarakat orang Banjar. Misalnya saja mengenai masalah hidup rumah tangga, perceraian, pekerjaan, poligami, dan seksualitas. Tema-tema ini disesuaikan pula dengan konteks masyarakat Banjar yang mayoritas beragama Islam dan memegang nilai-nilai Islam dalam berbagai hal mulai dari cara berpakaian, tata kelakuan, upacara adat, hingga aturan-aturan pemerintahan di sana. Untuk menghasilkan cerita-cerita Si Palui, selain menonton berita, Yustan Aziddin sering bertandang ke warung kopi untuk bertukar cerita dengan para pengunjung di sana. Penulis pertama Si Palui adalah sosok yang rajin menulis dan selalu memiliki stok cerita untuk setiap edisi Banjarmasin Post. Setelah Yustan Aziddin pensiun, cerita Si Palui ditulis oleh Abi Karsa, seorang politikus. Tidak heran, pada zamannya cerita Si Palui sangat kental dengan muatanmuatan politik. Generasi ketiga penulis Si Palui adalah Husni Thamrin, seorang pekerja sosial. Rombakan yang cukup besar terjadi di generasi ketiga Si Palui.

Tema yang diangkat lebih umum, berasal dari tuturan kebanyakan orang Banjar dan menceritakan kisah dari berbagai kalangan kelas sosial. Pada generasi ketiga ini cerita Palui bisa dinikmati oleh banyak kalangan, mulai dari kalangan bawah hingga atas. Selain rombakan pada tema, bahasa Banjar yang digunakan juga berbeda. Pada masa penulis ketiga, bahasa Banjar yang digunakan dalam Si Palui adalah bahasa Banjar Kuala, yakni bahasa Banjar yang biasanya digunakan masyarakat di daerah Banjarmasin dan Marabahan.

Sepeninggal Husni Thamrin, Si Palui mengalami masa transisi-masa kekosongan penulis tetap Si Palui. Kekosongan itu diisi Banjarmasin Post dengan cara terus menerbitkan kembali kisah Si Palui yang lama-judulnya saja yang diganti. Pada masa penulisan kolom Si Palui oleh Husni Thamrin, mulai banyak cerita yang menghadirkan tokoh perempuan. Jika pada tulisan-tulisan Yustan Aziddin si Palui dan tokoh-tokoh perempuan hadir untuk memberikan nasihat dan tuntunan, pada tulisan Abi Karsa tokoh perempuan tidak banyak hadir. Ketidakhadiran perempuan dalam kolom yang ditulis oleh Abi Karsa adalah karena perempuan dianggap tidak ikut andil dalam dunia politik. Pada tulisan Husni Thamrin, perempuan banyak hadir dan menjadi objek humor Si Palui. Humor pada tulisan-tulisan Husni Thamrin cenderung berifat seksis dan berbau pornografi karena humor yang seperti itu dianggap lebih banyak peminatnya dibanding tema-tema yang lain.

Hingga kini, Banjarmasin Post masih terus mencari generasi penerus penulis $\mathrm{Si}$ Palui yang memiliki karakter tersendiri. Harapannya, penulis generasi terbaru bisa sekuat generasi ketiga penulis $\mathrm{Si}$ Palui terdahulu. Saat ini cerita Si Palui yang beredar hanya berkisar pada aktivitas sehari-hari yang bisa ditanggapi, dikomentari, bahkan disindir melalui humor. Terlalu muluk untuk mengharapkan cerita Palui kembali seperti pakem penulis pertama yang sarat nasihat dan tuntunan. Tekanan Banjarmasin Post 
dalam penulisan Si Palui adalah kekuatan dialog antartokoh. Tidak semata Palui yang menjadi penutur tunggal, tetapi juga hadir tokoh-tokoh lain di sekitarnya seperti Garbus, Tulamak, dan lainnya.

\section{Representasi Perempuan dalam Kolom Si Palui}

Tokoh perempuan dalam kolom Si Palui ditempatkan sebagai tokoh figuran. Tokoh perempuan pada awalnya jarang hadir karena Si Palui yang seorang laki-laki merupakan tokoh utama dan pusat cerita. Perempuan lebih banyak menjadi objek dari cerita lucu dalam kolom Si Palui.

Representasi sebagai bagian dari praktik diskursus tidak pernah lepas dari efek struktural yang menyertainya. Oleh karena itu Fairclough (1989: 74) mengemukakan bahwa dalam sebuah proses diskursus, terdapat pembagian sistematis yang kemudian menghasilkan sebuah relasi sosial. Pembagian ini melihat bagaimana (1) subjek memiliki efek untuk mencirikan sebuah identitas sosial; (2) relasi antarsubjek yang merepresentasikan relasi sosial; dan (3) konten yang merepresentasikan sebuah pengetahuan. Representasi ini hadir baik melalui gambar maupun bahasa dan narasi yang digunakan untuk mendeskripsikan sesuatu. Berangkat dari analisis wacana Norman Fairclough, Fairclough (1995: 98) mengemukakan bahwa teks dianalisis dengan critical linguistic atau membedah teks melalui elemen-elemen linguistik. Pada penelitian ini, elemen linguistik yang dipakai adalah elemen semantik, sintaksis, dan leksikon. Melalui ketiga elemen tersebut dapat dilihat representasi yang muncul di dalam teks.

Pada teks Janda Kambang, Mancariakan Abahnya dan Baubah Banar, representasi tentang perempuan berstatus janda muncul. Pertama, tentang sebutan janda kembang Konstruksi tentang perempuan janda dalam teks 'Janda Kembang' dilakukan oleh tokoh kepala desa yang mengemukakan "carikan aku perempuan.. jandapun tidak apaapa asal mau kujadikan istri." Kalimat ini menunjukkan bahwa perempuan dinilai dari status perkawinannya-lajang atau janda.

Pada cerita Si Palui ini tidak diceritakan alasan kepala desa memilih janda untuk menjadi istrinya. Namun berefleksi pada kalimat yang diucapkannya, "janda” seolaholah selalu mau jika diajak menikah lagi setelah bercerai atau setelah suaminya meninggal. Di awal cerita, kepala desa hanya diceritakan mencari istri lagi karena istrinya meninggal.Cerita ini dilanjutkan dengan Si Palui yang menawarkan seorang janda kembang kepada kepala desa. Janda kembang dalam Kamus Besar Bahasa Indonesia (KBBI) berarti "janda muda yang cantik dan belum beranak.” Berdasarkan definisi ini, terdapat pemahaman bahwa seorang perempuan yang menyandang gelar "janda kembang” pasti memiliki wajah yang cantik.

Cerita Mancariakan Abahnya juga membangun makna janda. Suatu kali Palui mendekati Inur, janda montok beranak dua di desanya. Palui nekat mendekati Inur karena ia merasa Inur memberi kesempatan untuk didekati. Menurut cerita Palui, Inur mengemukakan bahwa ia mencari ayah untuk anaknya. Palui pun sepakat untuk menerima anak-anak Inur tersebut. Ternyata, setelahnya Inur justru menikah dengan laki-laki lain. Garbus dan Tulamak pun menertawakan Palui. Pada cerita ini, seorang janda digambarkan sebagai tokoh yang tidak bertanggung jawab dan menjebak laki-laki yang ingin menikahinya. Janda Inur diceritakan menggunakan kalimat yang ambigu bahwa ia mencarikan ayah untuk anaknya. Si Palui yang berpikir bahwa seorang perempuan yang mencari ayah untuk anaknya berarti juga mencari suami untuk dirinya.

Pada Cerita Baubah Banar pembangunan makna atas perempuan ditunjukkan oleh perubahan sikap Aluh Langkar yang dulu pemarah dan tidak tertarik dengan Palui, kini setelah suaminya meninggal menyuruh Palui cepat-cepat menikahinya.

Dari cerita di atas, dapat dilihat bahwa status perempuan, khususnya janda digambarkan sebagai tokoh yang ingin segera menikah lagi agar terlepas dari status janda, 
suka merayu, dan manja.

\section{Melabeli Tubuh Perempuan}

Pada teks humor $\mathrm{Si}$ Palui, tokoh perempuan seringkali mendapat 'label' melalui kosakata tertentu. Pada pemberian label ini, kata yang dipakai dibagi menjadi dua: merujuk secara langsung dan tidak langsung. Kata-kata yang langsung merujuk pada perempuan adalah kosakata-kosakata yang dipakai untuk melabeli tubuh perempuan dan status perempuan itu sendiri. Dari lima cerita, kosakata tersebut antara lain: 'montok', 'janda kembang', 'janda beranak satu', 'gincu' (atau pemerah bibir, yang merujuk pada bibir yang ingin dicium), 'kada kaawakan' dan 'kauyuhan malayani aku' yang merujuk pada perempuan yang tidak sanggup melayani kebutuhan seksual laki-laki.

Selain itu, pada kata-kata yang tidak langsung merujuk pada perempuan memiliki kecenderungan berupa kata-kata yang berhubungan dengan seksualitas. Kata-kata tersebut antara lain 'kimpoi' dan 'kuntau' yang merujuk pada berhubungan seksual. Kuntau sendiri memiliki makna harafiah sebagai perkelahian satu lawan satu. Tetapi di cerita Si Palui, kuntau dimaknai sebagai berhubungan seksual. Selain dua kata tersebut, berhubungan seksual juga dirujuk dengan kosakata lain seperti 'bahintaluan' yang mengasosiasikan berhubungan seksual dengan bertelur pada binatang, 'dikejar terus siang dan malam' untuk menunjukkan kegiatan seksual berkali-kali dalam satu hari dan 'banyak bapatak di rumah'. Terkait dengan seksualitas, frasa 'dua buah pabriknya tokcer' merujuk pada organ reproduksi yang berfungsi dengan baik dan tidak ada pihak yang mandul. Pada persoalan seksualitas, kata 'bagandakan' atau berpacaran, 'diparai' atau nikah siri juga disebutkan dalam kolom Si Palui sebagai salah satu bentuk proses pendekatan antara perempuan dan laki-laki. Jujuran atau mas kawin merupakan syarat dalam pernikahan adat Banjar.

\section{Perempuan dan Isu Seksualitas dalam}

\section{Humor}

Selain persoalan status, perempuan dalam teks Si Palui juga dilekatkan dengan persoalan seksualitas. Pemaknaan mengenai seksualitas dapat dilihat dari teks-teks Si Palui yang berjudul Cagar Batiga dan Cangkir Baciri.

Cerita Cagar Batiga menceritakan hidup berumah tangga si Palui yang sudah tiga tahun namun belum juga memiliki anak. Selama tiga tahun itu juga, Palui berusaha dengan memeriksakan diri, mulai dari ke dokter hingga ke pengobatan tradisional. Separuh dari cerita ini mengisahkan obrolan si Palui dan Garbus terkait Palui yang belum juga memiliki anak. Garbus menanyakan kemungkinan-kemungkinan yang menyebabkan istri Palui belum juga hamil seperti: kandungan istri Palui yang lemah, sperma Palui yang tidak subur karena terlalu tua menikah. Persoalan rumah tangga $\mathrm{Si}$ Palui yang belum memiliki anak disebabkan karena istri Palui yang telalu lelah, sedangkan Palui tidak memiliki masalah reproduksi. Hal ini kemudian dipertegas pada paragraf selanjutnya, paragraf enam dan tujuh:

"Mungkin salahmu juga yang tidak ingat, dikejar terus siang dan malam," ejek Garbus. (p.6)

"Aku tidak mau juga seperti itu Bus, tapi si utuh ini yang tidak bisa tahan, tidak bisa terlena sedikit," ujar Palui. (p.7)

Dari percakapan diatas, mulai terbangun makna konotasi seksual dalam kolom humor ini. "Dikejar terus siang malam" bermakna tentang berhubungan seksual yang dilakukan berkali-kali dalam satu hari. Hal ini yang dimaknai Garbus sebagai sumber kelelahan istri Palui, yakni melayani kebutuhan seksual suaminya. Di sisi lain, jawaban Palui bahwa ia tidak menginginkan hal itu tetapi "Si Utuh yang tidak bisa tahan" bermakna bahwa ia tidak mampu membendung hasrat seksualnya. Ia mengemukakan bahwa organ reproduksinya (penisnya) yang memiliki kontrol tersebut. Dalam hal ini, Palui

1 Si Utuh: Secara harafiah, "utuh" merupakan panggilan laki-laki dewasa dalam bahasa banjar. Dalam konteks ini, utuh berarti penis. 
membangun makna bahwa hasrat seksual laki-laki sulit untuk dibendung.

Sedangkan pada cerita Cangkir Baciri, diawali dengan ketertarikan Garbus dan Palui pada Aisah, keponakan penjaga warung. Pada cerita ini disebutkan bahwa Palui adalah seorang mata keranjang, atau dalam bahasa Banjar disebut liur baungan. Ia juga mendekati Aisah dan menantang Garbus untuk bersaing mendapatkan hati Aisah. Palui ingin melihat apakah yang menang adalah dia yang memiliki penis yang besar atau Garbus yang memiliki banyak uang.

Pada pemaknaan tentang seksualitas, perempuan dan laki-laki direpresentasikan secara berbeda. Laki-laki digambarkan sebagai simbol yang aktif secara seksual dan perempuan menjadi objek seksual lakilaki. Hal ini ditunjukkan dari dialog Palui dan teman-temannya yang membicarakan persoalan alat kelamin. Terutama pada ranah fungsi alat kelamin sebagai organ reproduksi.

Pada lima teks $\mathrm{Si}$ Palui, tokoh perempuan yang hadir dapat dikelompokkan menjadi tiga: janda, istri, dan perempuan lainnya. Ketiganya memiliki representasi yang berbeda-beda. Pada cerita yang menghadirkan tokoh janda, yakni pada judul Janda Kambang, Mancariakan Abahnya, dan Baubah Banar menunjukkan representasi janda seperti sebutan janda kembang, berbadan montok, sifatnya manja, dan ingin segera dinikahi untuk melepas status jandanya. Janda yang disebut sebagai janda kembang, didefinisikan sebagai perempuan muda dan cantik sehingga menarik perhatian laki-laki. Hal ini tercermin pada cerita Janda Kambang.

Representasi seorang janda yang berbadan montok hadir hampir di semua teks tentang janda, kecuali pada judul Janda Kambang. Bahkan, pada teks Baubah Banar diceritakan nama tokoh jandanya adalah Aluh Langkar. Aluh merupakan kata panggilan bagi perempuan dewasa di masyarakat Banjar. Representasi sifat manja seorang janda dikisahkan pada cerita Mancariakan Abahnya, ketika janda di kampung Palui bersikap manja agar Palui luluh dan meluluskan permintaan janda tersebut. Representasi ini menunjukkan perempuan sebagai perayu laki-laki.

Representasi bahwa janda ingin segera dinikahi terkait dengan pandangan bahwa perempuan harus memiliki suami sebagai penjaga. Tidak jarang seorang janda bersedia menikah lagi hanya karena ingin mengejar status sebagai istri seseorang sehingga ia terhindar dari cemoohan masyarakat. Hal ini direpresentasikan pada teks Baubah Banar yang menceritakan seorang janda yang meminta untuk segera dinikahi.

Berbeda dari representasi janda yang diceritakan dari bentuk fisik, representasi perempuan sebagai istri tidak membahas bentuk tubuh perempuan melainkan dengan representasi kegiatan seks yang dilakukan sebagai suami-istri. Pada teks Cagar Batiga tokoh istri Palui diceritakan sebagai perempuan yang sering kelelahan karena melayani kebutuhan seksual si Palui.

Kelompok ketiga adalah representasi perempuan lain dalam kolom Si Palui. Perempuan dalam kelompok ini terdiri dari tokoh ibu mertua Palui dan perempuan lajang penjaga warung. Representasi ibu Mertua Palui ditunjukkan pada teks Cagar Batiga, yakni sebagai perempuan yang cerewet tapi penakut. Sedangkan perempuan lajang penjaga warung dikisahkan sebagai perempuan yang baik hati dan tidak sungkan menunjukkan perasaannya kepada Palui dengan memberikan gelas dengan bekas lipstiknya.

Selain melihat representasi perempuan dari tokoh yang diperankan dalam teks, pembedahan teks Si Palui yang menunjukkan representasi perempuan berefleksi pada penelitian Laura Mulvey (1975) mengenai representasi perempuan dalam film. Mulvey (dalam Storey 2015: 110), mengemukakan bahwa posisi perempuan dalam suatu media ditampilkan sebagai objek erotis (erotic object) dalam dua level. Pertama, sebagai objek erotis dalam narasi media, yakni bahwa karakter perempuan dalam media ditransformasikan sebagai objek hasrat dari tokoh laki-laki. Kedua, perempuan menjadi objek erotis dari penonton itu sendiri. Citra 
perempuan dalam media tidak pernah lepas dari sudut pandang laki-laki sebagai penonton. Hal ini juga yang tampak pada kolom-kolom Si Palui. Perempuan tidak pernah lepas dari sudut pandang tokoh lakilaki dalam cerita.

Merujuk pada argumen Laura Mulvey di atas, bahwa perempuan menjadi objek erotis dalam narasi media, ditunjukkan dengan kata kunci yang muncul dalam cerita-cerita Si Palui yang telah dikumpulkan. Kata kunci yang muncul dalam cerita Si Palui terdiri atas istilah, idiom, dan kata-kata yang memiliki asosiasi terhadap perempuan dan seksualitas. Pada cerita-cerita Si Palui, perempuan yang hadir dalam cerita dikaitkan dengan isu seksualitas yang terbagi atas dua hal-tentang tubuh perempuan dan tentang hubungan seksual. Mengenai tubuh perempuan, kata-kata yang dipakai dan merujuk pada tubuh perempuan antara lain "langkar" (montok), "susu" (payudara), dan bekas gincu yang merujuk pada bibir perempuan. Kata "langkar" atau montok, dalam bahasa Banjar selalu saja merujuk pada perempuan dan tidak pernah dipakai untuk mendeskripsikan laki-laki.

Sedangkan kata kunci yang muncul yang merujuk pada hubungan seksual adalah "kimpoi," "kuntau," "bahintaluan," "banyak bapatak di rumah" sebagai ungkapan untuk berhubungan seksual, "kadakaawakan" (tidak sanggup melayani kebutuhan seksual lakilaki), "baliur" untuk merujuk bernafsu untuk menikahi perempuan. Di sisi lain, laki-laki hadir sebagai subjek dari isu-isu seksualitas itu. Kata kunci yang muncul antara lain "tuatua keladi," "kijil wan kidasnya" yang merujuk pada sifat tokoh laki-laki yang genit dan suka merayu perempuan, "barang" dan "utuh" yang merujuk pada penis, "liur baungan" yang dalam cerita diterjemahkan sebagai mata keranjang.

Kehadiran perempuan sebagai objek erotis jelas saja memiliki tujuan tertentu. Pengobjekan perempuan ini bertujuan untuk menarik perhatian pasar. Berefleksi pada penelitian Dwi Ratna Aprilia (2005) tentang perempuan sebagai model iklan, terdapat beberapa alasan mengapa perempuan dijadikan model dalam iklan. Salah satunya adalah erotisme tubuh perempuan dijadikan stopping power (kekuatan yang digunakan agar orang memperhatikan iklan yang ada di $\mathrm{TV}$, radio, majalah, koran, dan lain sebagainya (Aprilia, 2005: 50) yang mengukuhkan stereotip tentang perempuan, baik yang positif (seperti lemah lembut) hingga yang negatif (seperti bertugas di ranah domestik dan sebagai simbol seks).

Pada teks Si Palui, seperti yang dapat dilihat di atas, pengukuhan akan stereotip ini tampak jelas terutama pada stereotip negatif kepada perempuan sebagai simbol seks. Hal ini diamini oleh pihak Banjarmasin Post dalam wawancara tanggal 22 Juni 2016 bahwa humor Si Palui merujuk pada pornografi karena minat pasaryang besaratas humor yang bertema pornografi. Kehadiran pasar bagi humor Si Palui, khususnya yang bertemakan pornografi, kemudian menjadikan perempuan sebagai bagian dari komoditas atas produk media berjudul kolom Si Palui.

Tokoh perempuan yang hadir dalam kolom Si Palui sebagai komoditas cerita menempati posisi pada level kedua, di mana perempuan menjadi objek erotis dari penonton laki-laki. Hal ini dapat dilihat dari bagaimana perempuan dideskrispsikan dari sudut pandang laki-laki sebagai penonton. Dari lima cerita yang dikumpulkan, deskripsi perempuan dari sudut pandang laki-laki ini ditunjukkan oleh dua hal: Pertama, keterlibatan aktif perempuan dalam cerita. Dari lima cerita, hanya dua cerita yakni Cagar Batiga dan Cangkir Baciri. Dari dua cerita tersebut, cerita yang memuat perempuan sebagai bagian dari akhir humor yang menukik adalah cerita Cagar Batiga. Sedangkan pada cerita Cangkir Baciri, argumentasi dari perempuan dikisahkan sekilas dan hanya menjadi penambah dalam cerita. Keterlibatan aktif perempuan juga tidak berada pada porsi yang seimbang dengan porsi laki-laki dalam cerita. Kedua, deskripsi tentang perempuan dilakukan oleh laki-laki. Perempuan tidak diberi tempat untuk mendeskripsikan dirinya sendiri.

Argumen Laura Mulvey di atas juga 
diteguhkan oleh Anwar (2009) yang mengemukakan bahwa fenomena kultural tentang gender melihat bahwa perempuan hidup dalam eksistensi sosial yang terkungkung dan terkekang oleh budaya patriarki. Pada fenomena ini hadir sebuah kondisi di mana perempuan hidup dalam dualitas kultural-sebagai anggota kultur umum laki-laki dan dalam kultur perempuan yang spesifik. Dualitas kultural yang menyelimuti kehidupan perempuan tersebut yang kemudian menimbulkan konflik subjek-objek, yang dalam kebudayaannya didominasi oleh laki-laki, sementara perempuan dianggap sebagai jenis kelamin kedua (liyan) dalam sistem kebudayaan patriarki. Pada cerita Si Palui, representasi tentang perempuan menjadi liyan ketika laki-laki tidak hadir dalam kehidupannya sehari-hari, entah karena meninggal atau bercerai.

Oleh karena itu, pada cerita Si Palui yang menghadirkan tokoh janda seperti Mancariakan Abahnya dan Baubah Banar digambarkan bahwa status janda selalu lekat dengan usaha untuk menikah lagi. Pada cerita Mancariakan Abahnya diceritakan janda di kampung Palui kembali berpacaran dengan mantan pacarnya. Pada cerita Baubah Banar diceritakan bahwa janda berusaha mencari pasangan lagi setelah suaminya meninggal. Cerita yang berbeda terdapat pada Janda Kambang yang mengisahkan tentang lakilaki yang mencari pasangan setelah istrinya meninggal.

Marla Mies (Mies dalam Omara, 2004: 149) mengemukakan bahwa ideologi patriarki merupakan serangkaian sistem nilai yang menempatkan laki-laki pada posisi yang lebih tinggi daripada perempuan. Hal ini yang kemudian menempatkan posisi laki-laki dalam sebuah budaya sebagai pihak yang dominan sedangkan perempuan pada pihak yang subordinat. Subordinasi perempuan dipraktikkan dalam berbagai cara. Pada kolom Si Palui, potonganpotongan cerita mengenai janda yang minta segera dinikahi seperti cerita Baubah Banar yang menunjukkan bahwa posisi laki-laki penting dalam kehidupan sosial, khususnya pada posisi laki-laki sebagai suami dan kepala keluarga. Cerita-cerita kolom Si Palui yang menyertakan perempuan di dalamnya tampak sekali bahwa dalam kolom ini perempuan memiliki posisi nomor dua setelah laki-laki. Dikatakan demikian karena dari kolom-kolom Si Paluiyang dikumpulkan, perempuan menjadi bahan humor, mulai dari mencirikan perempuan dari bentuk tubuhnya yang menonjol, status sosialnyapada cerita Si Palui merujuk pada jandadan yang menonjol adalah posisi perempuan sebagai objek erotis dalam cerita.

Pada cerita Si Palui memang tidak tampak ada kasus kekerasan dalam rumah tangga seperti pemukulan dan sebagainya. Namun dalam kolom ini, "kekerasan" justru dilakukan dengan memberikan capcap tertentu kepada perempuan, terutama pada status janda. Mendapatkan predikat janda (baik karena bercerai maupun karena suaminya meninggal) sekaligus akan memberikan cap buruk kepada perempuan tersebut, bahwa perempuan tidak lagi dihargai sebagai dirinya sendiri. Karena tidak adanya laki-laki sebagai suami, ia justru digoda, meminta segera dinikahi, atau sebaliknya justru menjadi sasaran untuk menjadi istri muda.

\section{SIMPULAN}

Si Palui merupakan kolom humor yang tidak serta merta hadir di Kalimantan Selatan. Palui telah melewati perjalanan panjang sebagai tokoh yang diceritakan dalam budaya lisan bahasa Banjar, sebelum akhirnya menjadi kolom cerita bahasa Banjar di Banjarmasin Post dengan tujuan untuk mengangkat budaya lokal melalui kolom humor. Humor Si Palui yang "merakyat" ini ditunjukkan dengan cerita-cerita yang lebih familiar, yang diambil dari kejadian seharihari dan membahas persoalan yang biasa terjadi di masyarakat, seperti persoalan rumah tangga. Pada cerita Palui yang bertema rumah tangga, beberapa tema yang sering hadir adalah poligami, perceraian, dan seksualitas suami istri. Pada kolom Si Palui, tokoh yang terlibat dalam cerita antara lain 
adalah Palui, Tulamak, dan Garbus. Tokoh yang lain, seperti kepala desa atau tokohtokoh perempuan, hadir sebagai figuran.

Representasi perempuan dalam teks $\mathrm{Si}$ Palui terbagi menjadi tiga: sebagai janda, istri, dan status perempuan lain digambarkan berbeda-beda. Sebagai janda, digambarkan sebagai tokoh yang berbadan montok, manja, dan ingin segera menikah. Tokoh janda yang mendapat penegasan dalam kolom Palui adalah janda kembang yang menjadi idola laki-laki. Tokoh istri digambarkan sebagai objek seksual suaminya. Perempuan lain, seperti mertua, digambarkan cerewet, dan perempuan lajang diceritakan agresif. Di sisi lain, Palui diceritakan sebagai tokoh yang memiliki banyak teman, pintar bergaul, agresif, dan suka menggoda perempuan. Pada kolom Si Palui, pilihan-pilihan kata pada teks merupakan terminologi bahasa Banjar yang hanya dipakai untuk merujuk pada perempuan dan tidak dipakai untuk laki-laki seperti "langkar" (montok), "ungah" (manja) dan "janda kambang” (janda kembang). Teks humor Si Palui menempatkan perempuan pada posisi objek humor. Hal ini tidak lepas dari faktor penulis Si Palui yang semuanya adalah laki-laki dan tidak pernah ada penulis perempuan yang terlibat dalam penulisan kolom Si Palui.

Oleh karena itulah, humor-humor yang hadir dalam teks Si Palui adalah humor yang sifatnya seksis. Terkait dengan kolom Si Palui, penempatan posisi laki-laki yang lebih tinggi dari perempuan ditunjukkan dari ketidakhadiran perempuan untuk ikut berargumen dalam cerita. Ketidakhadiran ini membuat tokoh laki-laki dapat lebih bebas mengemukakan pendapatnya tentang perempuan, bahkan menjadikan perempuan sebagai objek humor. Terlebih lagi, humor Palui yang terkait dengan perempuan diasosiasikan dengan seksualitas.

\section{DAFTAR PUSTAKA}

Anwar, Ahya. (2009). Geneologi Feminis: Dinamika Pemikiran Feminis dalam Novel Pengarang Perempuan Indonesia 1933-2005. Jakarta: Republika.

Aprilia, Dwi Ratna. (2005). "Iklan dan Budaya Popular: Pembentukan Identitas Ideologis Kecantikan Perempuan oleh Iklan (Analisis Semiotika Iklan Cetak WRP Body Shape \& Prolene)". Jurnal Ilmu Komunikasi. No. 1 vol 2, hlm 4165.

Baubah Banar. (2016, Maret 2). Banjarmasin Post hlm. 14 diakses melalui https:// is suu.com/deny_bpost / docs / bp20160302.

Cagar Batiga. (2016, Maret 17). Banjarmasin Post hlm. 14 diakses melalui https:// is suu.com/deny_bpost / docs / bp20160317.

Cangkir Baciri. (2016, Maret 23) Banjarmasin Post hlm. 14 diakses melalui https:// is suu.com/deny_bpost/docs / bp20160323

Fairclough, Norman. (1989). Language and Power. London: Longman.

(1995). Critical Discourse Analysis: The Critical Study of Language. London: Longman.

Hall, Stuart. (1997). Representation. London: Sage Publication.

Janda Kambang. (2016, Januari 19). Banjarmasin Post hlm. 14 diakses melaluihttps://issuu.com/deny_bpost/ docs/bp20160119.

Mancariakan Abahnya. (2016, Januari 26). Banjarmasin Post hlm. 14 diakses melaluihttps://issuu.com/deny_bpost/ docs/bp20160126.

Maryam, Siti. 2014. "Analisis Wacana Humor dalam Kumpulan Komik Serial Mice Cartoon”. Tesis. Yogyakarta: Universitas Gadjah Mada. 
Omara, Andy. (2004). "Perempuan, Budaya Patriarki, dan Representasi”. Mimbar Hukum, No.2, hlm 148-165.

Pilliang, Y.A. (2004). “Semiotika Teks: Sebuah Pendekatan Analisis Teks". Jurnal Mediator. No. 2 (5) hlm. 189-198.

Pormes, F.S. (2015). Analisis Humor Epen Kah Cupen To. Tesis. Yogyakarta: Universitas Gadjah Mada.

Rizkie, I.H. (2013). "Pelanggaran Prinsip Kerja Sama dan Implikatur Wacana Humor dalam Rubrik "Mesem" Surat Kabar Harian Warta Jateng". Skripsi. Surakarta: Universitas Muhammadiyah Surakarta.

Storey, John. (2015). An Introductory Guide To Cultural Theory and Popular Culture. New York: Routledge.
Thornham, Sue. (2010). Teori Feminis dan Cultural Studies. (Asma Bey Mahyuddin, Terjemahan).Yogyakarta: Jalasutra.

Vidiadari, Irene Santika. (2013). "Resepsi Pembaca Perempuan Banjar Muslim Terhadap Kolom Si Palui dengan Tema Perceraian dan Poligami di Surat Kabar Harian Banjarmasin Post dengan Pendekatan Encoding-Decoding Stuart Hall”. Skripsi. Yogyakarta: Universitas Atma Jaya Yogyakarta.

Wijana, I dewa Putu. (1995). "Wacana Kartun dalam Bahasa Indonesia”. Disertasi. Yogyakarta: Universitas Gadjah Mada.

Yuniawan,Tommi.(2005).“TeknikPenciptaan Asosiasi Pornografi dalam Wacana Humor Bahasa Indonesia”. Humaniora No.3 (Vol 17). hlm. 285-292. 
